\title{
Examination of the epicardial fat area in patients with rheumatoid arthritis by computed tomography of the thorax
}

\section{Romatoid artrit hastalarında epikardiall yağ alanının toraks bilgisayarlı tomografi ile incelenmesi}

\author{
Nisa Bașpınar ${ }^{1}$, Orhan Solak ${ }^{2}$, İsmail Şalk ${ }^{2}$, Ferhat Sezer ${ }^{3}$
}

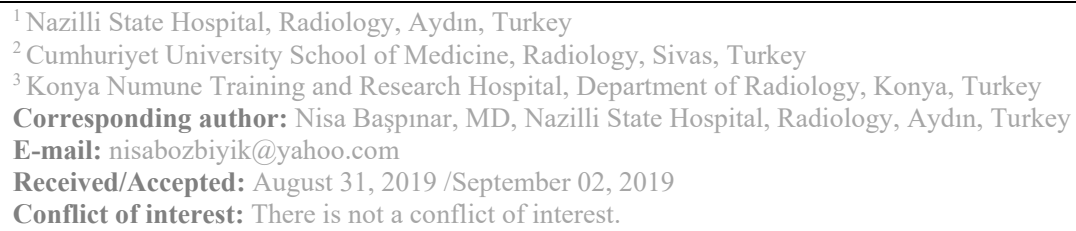

\begin{abstract}
SUMMARY
Objective: Rheumatoid arthritis (RA) is an autoimmune and inflammatory disease. The prevalence of cardiovascular diseases (CVDs) increases in RA. The CVDs were shown as the primary cause of death in RA. In this study, it was aimed to determine the difference between the patients and the control group by measuring the epicardial adipose tissue (EAT) at the left major coronary artery, which is known as one of the significant risk factors for CVDs in RA patients who underwent computerized tomography (CT) of the thorax due to any reason, through the CT.

Method: The study includes 87 patients diagnosed with RA in the remission period and 45 healthy people as the control group. The files and archive records were reviewed and the clinical features of the patient and control groups, the EAT areas in the thorax CT performed, ascending aorta, pulmonary truncus, and pulmonary artery diameters, as well as, the cardiothoracic rates (CTR) measured with CT were recorded.

Results: There was no significant difference between the groups in terms of age and gender $(p>0.05)$. It was determined that the EAT measured with CT increased in patients diagnosed with RA compared to the control group and this increase was strictly related to the aortic and pulmonary artery width $(p<0.05)$. In addition, the increase in the EAT area was directly proportional to the CTR in patients diagnosed with RA $(\mathrm{p}<0.05)$. It was seen that the ascending aorta diameter, pulmonary truncus diameter, and right and left pulmonary artery diameters increased compared to the control group $(\mathrm{p}<0.05)$.
\end{abstract}

Conclusions: In the present study, it was determined that the EAT measured with CT increased in patients with RA compared to normal people, and this increase was firmly related to the aortic and pulmonary artery width. In addition, the increase in the EAT area was directly proportional to the CTR in patients diagnosed with RA. The patients with RA were under a significant risk compared to ordinary people in terms of the development of CVDs. It is considered that more prospective studies including patients diagnosed with RA should be conducted.

Keywords: Rheumatoid arthritis, epicardial adipose tissue, eat, cardiovascular disease, computerized tomography 
Amaç: Romatoid artrit (RA), otoimmün ve inflamatuvar bir hastalıktır. RA'da kardiyovasküler hastalıklar (KVH) prevelansı artmıştır. RA'da major ölüm sebebi olarak KVH gösterilmiştir. Bu çalışmada amacımız herhangi bir nedenle toraks bilgisayarlı tomografi (BT) yapılmış RA hastalarında KVH açısından majör risk faktörlerinden biri olarak bilinen epikardiyal yağ dokusu (EYD) alanının sol ana koroner arter seviyesinde BT ile ölçülerek kontrol grubu ile farkın belirlenmesi amaçlanmıștır.

Materyal ve Metod: Çalı̧̧maya remisyon periyodunda bulunan 87 hasta ile control grubuna 45 sağlıklı kişi dahil edildi. Dosya ve arşiv kayıtları incelenerek hasta ve kontrol grubunun klinik özellikleri ve yapılmış olan toraks BT de EYD alanı, asendan aorta, pulmoner trunkus, pulmoner arter çapları ve kardiyotorasik oran (KTO) ölçülerek kayıt altına alındı.

Bulgular: Gruplar arasında yaş ve cinsiyet açısından anlamlı fark yoktu ( $\mathrm{p}>0.05)$. BT ile ölçülen EYD'nin RA tanılı hastalarda kontrol grubuna göre arttığı ve bu artışın aort ve pulmoner arter genişliği ile yakından ilişkili olduğu tespit edildi $(\mathrm{p}<0.05)$. Ek olarak, EYD artış, RA tanılı hastalarda KTO ile doğru orantılıydı ( $<<0.05)$. Asendan aort çapı, pulmoner trunkus çapı, sağ ve sol pulmoner arter çaplarının kontrol grubuna göre arttığı görüldü ( $\mathrm{p}<0.05$ ).

Sonuç: Bu çalışmada, BT ile ölçülen EYD'nin RA'li hastalarda normal insanlara göre arttığı ve bu artışın aort ve pulmoner arter genişliği ile yakından iliş̧kili olduğu tespit edildi. Ek olarak, EYD'de artış, RA tanılı hastalarda KTO ile doğru orantılıydı. RA'lı hastaların, KVH gelişimi açısından normal insanlara göre önemli bir risk altında olduğu görülmüştür. RA tanısı konan hastalarda daha çok prospektif çalışmanın yapılması gerektiği düşünülmektedir.

Anahtar sözcükler: Romatoid Artrit, epikardiyal yağ dokusu, EYD, kardiyovasküler hastalık, Bilgisayarlı Tomografi

\section{INTRODUCTION}

Rheumatoid arthritis (RA) is an autoimmune and inflammatory disease. Its prevalence in different populations varies between $0.4 \%$ and $1 \%{ }^{1,2}$. Although it occurs at any age, it is more common between the ages of 35-60. In females, it is seen 23 times more than males ${ }^{3}$. RA, which is a chronic multisystemic and inflammatory disease, is associated with significant complications in cardiovascular system ${ }^{4,5}$. Cardiac involvement in RA may include pericarditis, myocarditis, endocarditis, coronary artery disease, valvular lesions, conduction disturbances, and aortic involvement ${ }^{5-8}$. The prevalence of cardiovascular diseases (CVDs) increases significantly in the case of RA (4). CVDs were shown as the major reason for death in $\mathrm{RA}^{6,9}$.

Epicardial adipose tissue (EAT) is the thoracic visceral adipose tissue that extends between the myocardium and visceral pericardium, and it is seen as a significant cardiovascular risk factor ${ }^{10,11}$. The fact that EAT is a cardiovascular risk factor arises from the paracrine effects due to the microcirculation that it shares with the myocardium and its closeness to coronary arteries, and local inflammatory effects ${ }^{12-14}$. In large-scaled community studies conducted, it was accepted that the EAT volume is associated with atherosclerotic lesions and an independent indicator for CVDs ${ }^{15,16}$.

$\mathrm{CT}$ is a more sensitive imaging method compared to echocardiogram (ECHO) in the evaluation of EAT and, with appropriate software, it ensures obtaining independent and objective results of a person ${ }^{17-20}$. In this study, it was aimed to evaluate the EAT, a significant risk indicator for CVDs, through CT in RA patients and healthy people.

\section{MATERIAL AND METHODS}

Study Population:

This retrospective study was conducted with 87 patients diagnosed with RA and 45 healthy people as the control group between April 2012 and September 2014. The RA diagnosis was made in accordance with the ACR and EULAR criteria ${ }^{21,22}$. The RA group comprises of RA patients with positive rheumatoid factors who do not receive any treatment. The control group, however, included cases with normal laboratory findings who had normal CT results of the thorax recorded in the system.

\section{Inclusion criteria:}

Patients aged $\geq 18$ years, who were accepted in the RA remission period (in terms of clinic and laboratory results) and who signed the informed consent forms met the inclusion criteria for the study. The control group, however, included participants who did not have RA or any other inflammatory disease and who had similar demographic information with the RA group such as of age and gender.

Exclusion criteria:

Patients having the features mentioned below were not included in the study: patients with valvular heart disease, chronic obstructive pulmonary disease or any severe systemic disease, occlusive coronary artery disease, coronary failure, chronic liver disease, hypertension, stage 2 or more severe chronic renal failure, those who have DM history, 
pregnant women, patients with hypohyperthyroidism diagnosis, patients with the BMI value of $>25 \mathrm{~kg} / \mathrm{m}^{2}$, and those who have alcohol abuse. The study was carried out in accordance with the Helsinki Declaration. The informed consent form was signed by all patients. Permission was received from the Ethics Committee of Cumhuriyet University Medical Faculty (C.U.M.F.) (Date: 23/10/2014 Decision No: 2014$10 / 02)$.

\section{EAT Measurement with Computerized Tomography}

The present study was conducted by using the 128 section multidetector CT device (Aquilion, Toshiba Medical Systems, Tokyo, Japan) and the standard thorax CT protocol of this device. In patients lying in the supine position, the images were obtained with the parameters of KV: 120 , rotation time: 0,5 , pitch factor: 1,48 , helix pitch: 95, FOV: 370 , total scanning time: $4,3 \mathrm{sec}$, and total mAs: 180. Following the tomography, a reconstruction process was performed on the recorded images at a thickness of $5 \mathrm{~mm}$.

The thorax CT images of all persons in the study were received from the image archive system of
C.U.M.F. Department of Radiology and the EAT areas in the section at the left major coronary artery outlet were measured through the adipose analysis program (Aquarius iNtuition Edition ver 4.4.6, Tera Recon Inc., San Mateo, CA, ABD) present in the works station (Figure 1). The ascending aorta, pulmonary truncus right, and left pulmonary artery diameters of the RA and control groups were recorded (Figure 2). In addition, the cardiac thorax indexes (CTR) were measured in patients with RA and were recorded as increased $(\geq 0.5)$ or standard $(<50)$.

\section{Statistical Analysis:}

The SPSS 22.0 (IBM Corporation, Armonk, New York, United States) program was used in the analysis of the variables. In the evaluation of the data, the significance test was used for the difference between two mean values (Kolmogorov-Smirnov) when the parametric test assumptions are fulfilled, and the Chi-square and Mann Whitney $U$ tests were used when the parametric test assumptions are not fulfilled. The ROC analysis was used in the determination of the cut-off point and the $\mathrm{p}<0.05$ value was accepted as statistically significant.

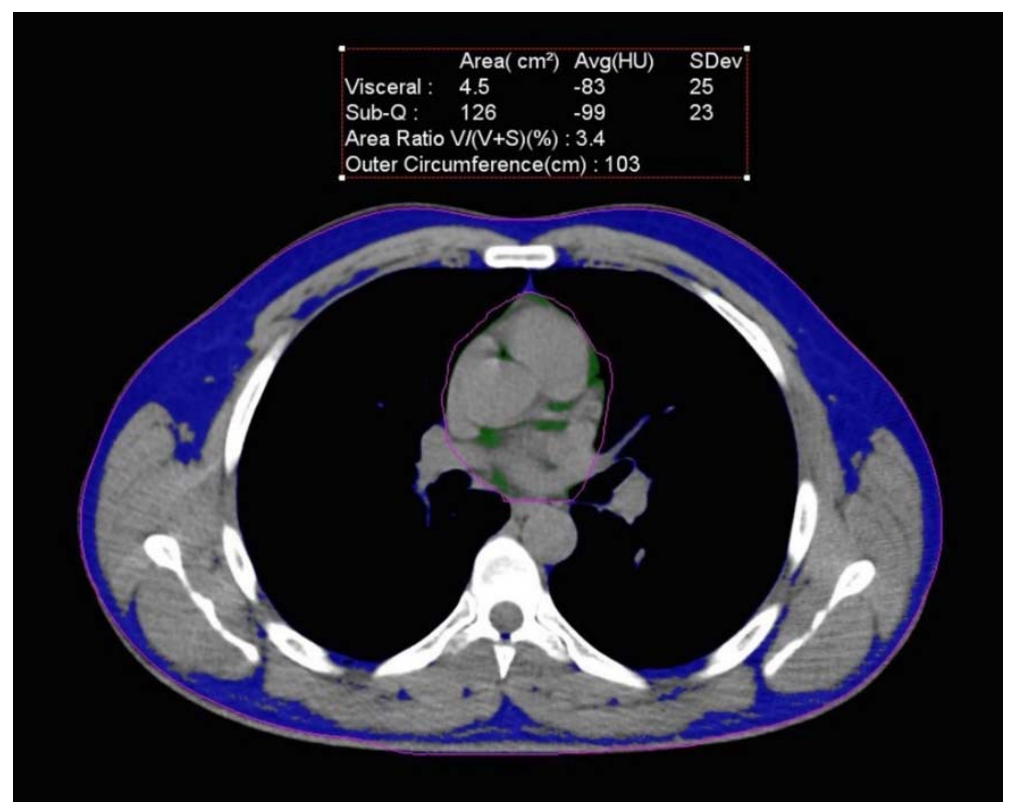

Figure 1: The measurement of epicardial adipose tissue at the left major coronary artery level with the adipose analysis (Aquarius iNtuition Edition ver 4.4.6, Tera Recon Inc., San Mateo, CA, ABD). 
between the groups in terms of age and gender ( $>00.05)$.

\section{RESULTS}

The study includes 87 RA patients with the mean age of $54.58 \pm 11.49$ years [15 (\%17.2) males, and 72 (\%82.8) females] and 45 healthy people with similar age and gender and the mean age of $51.86 \pm 11.83$ years $[11(24.4 \%)$ males, and 34 $(75.6 \%)$ females]. There was no difference
While there were significant differences between the RA and control groups in terms of epicardial adipose volume, ascending aorta diameter, pulmonary truncus diameter, and right and left pulmonary artery diameters $(\mathbf{p}<\mathbf{0 . 0 5})$, there was no significant difference in terms of other measurements $(\mathrm{p}>0.05)$ (Table 1).

Table 1: Cardiac and thorax CT measurement results of the patients with RA and the control group

\begin{tabular}{|c|c|c|c|c|}
\hline Variables & RA $($ Mean \pm SD) & $\begin{array}{c}\text { Control } \\
(\text { Mean } \pm \text { SD })\end{array}$ & \multicolumn{2}{|c|}{ Result } \\
\hline $\begin{array}{l}\text { Ascending aorta diameter } \\
(\mathrm{mm})\end{array}$ & $34.93 \pm 5.54$ & $30.97 \pm 2.87$ & $\begin{array}{l}\mathrm{t}=4.47 \\
\mathrm{p}=0.001\end{array}$ & $\mathbf{p}<\mathbf{0 . 0 5}$ \\
\hline $\begin{array}{l}\text { Pulmonary truncus diameter } \\
(\mathrm{mm})\end{array}$ & $26.05 \pm 5.16$ & $24.13 \pm 3.44$ & $\begin{array}{l}\mathrm{t}=2.25 \\
\mathrm{p}=0.026\end{array}$ & $\mathbf{p}<\mathbf{0 . 0 5}$ \\
\hline $\begin{array}{l}\text { Right pulmonary } \text { artery } \\
\text { diameter }(\mathrm{mm})\end{array}$ & $20.55 \pm 3.91$ & $19.02 \pm 2.61$ & $\begin{array}{l}\mathrm{t}=2.67 \\
\mathrm{p}=0.009\end{array}$ & $\mathbf{p}<0.05$ \\
\hline $\begin{array}{l}\text { Left pulmonary } \\
\text { diameter }(\mathrm{mm})\end{array}$ & $20.32 \pm 3.61$ & $18.40 \pm 2.48$ & $\begin{array}{l}\mathrm{t}=3.59 \\
\mathrm{p}=0.001\end{array}$ & $\mathbf{p}<\mathbf{0 . 0 5}$ \\
\hline $\begin{array}{lll}\text { Epicardial adipose } & \text { area } \\
\text { density }(\mathrm{HU}) & & \\
\end{array}$ & $-90.74 \pm 4.39$ & $-90.55 \pm 3.60$ & $\begin{array}{l}\mathrm{t}=0.25 \\
\mathrm{p}=802\end{array}$ & $\mathrm{p}>0.05$ \\
\hline Epicardial adipose area $\left(\mathrm{cm}^{2}\right)$ & $17.90 \pm 10.33$ & $11.92 \pm 5.24$ & $\begin{array}{l}\mathrm{t}=4.40 \\
\mathrm{p}=0.001\end{array}$ & $\mathbf{p}<0.05$ \\
\hline $\begin{array}{l}\text { Subcutaneous adipose } \text { area } \\
\text { density }(\mathrm{HU})\end{array}$ & $-105.73 \pm 8.16$ & $-105.77 \pm 7.86$ & $\begin{array}{l}\mathrm{t}=0.03 \\
\mathrm{p}=0.977\end{array}$ & $\mathrm{p}>0.05$ \\
\hline $\begin{array}{l}\text { Subcutaneous adipose area } \\
\left(\mathrm{cm}^{2}\right)\end{array}$ & $248.65 \pm 128.97$ & $225.68 \pm 128.87$ & $\mathrm{p}=0.209$ & $\mathrm{p}>0.05$ \\
\hline Thorax area $(\mathrm{cm})$ & $101.81 \pm 9.91$ & $105.57 \pm 11.15$ & $\begin{array}{l}\mathrm{t}=1.90 \\
\mathrm{p}=0.060\end{array}$ & $\mathrm{p}>0.05$ \\
\hline RA: Rheumatoid arthritis, HU: & $\begin{array}{r}\text { ounsfield Unit, } \mathbf{m} \\
\text { deviati }\end{array}$ & Millimeter, $\mathbf{c m :}$ & & tandard \\
\hline
\end{tabular}

When the measurements of females and males diagnosed with RA were compared, it was seen that the subcutaneous adipose area density, subcutaneous adipose area, and thorax area were more in females $(\mathbf{p}<\mathbf{0 . 0 5})$, while there was no difference in other parameters $(\mathrm{p}>0.05)$ (Table 2$)$. 
Table 2: Comparison of cardiac and thorax CT measurements of RA patients in terms of genders

\begin{tabular}{|c|c|c|c|c|}
\hline Variables & $\begin{array}{c}\text { Male } \\
(\text { Mean } \pm \text { SD })\end{array}$ & $\begin{array}{c}\text { Female } \\
(\text { Mean } \pm \text { SD })\end{array}$ & \multicolumn{2}{|c|}{ Result } \\
\hline Ascending aorta diameter (mm) & $34.26 \pm 3.32$ & $35.06 \pm 5.90$ & $\begin{array}{l}\mathrm{t}=0.50 \\
\mathrm{p}=0.613\end{array}$ & $\mathrm{p}>0.05$ \\
\hline $\begin{array}{l}\text { Pulmonary truncus diameter } \\
(\mathrm{mm})\end{array}$ & $24.80 \pm 3.56$ & $26.31 \pm 5.41$ & $\begin{array}{l}\mathrm{t}=1.03 \\
\mathrm{p}=0.303\end{array}$ & $\mathrm{p}>0.05$ \\
\hline $\begin{array}{l}\text { Right pulmonary artery } \\
\text { diameter }(\mathbf{m m})\end{array}$ & $21.13 \pm 3.15$ & $20.03 \pm 4.05$ & $\begin{array}{l}\mathrm{t}=0.63 \\
\mathrm{p}=0.053\end{array}$ & $\mathrm{p}>0.05$ \\
\hline $\begin{array}{l}\text { Left pulmonary artery diameter } \\
(\mathrm{mm})\end{array}$ & $19.93 \pm 2.71$ & $20.40 \pm 3.78$ & $\mathrm{t}=0.45 ; \mathrm{p}=0.65$ & $\mathrm{p}>0.05$ \\
\hline $\begin{array}{l}\text { Epicardial adipose area density } \\
\text { (HU) }\end{array}$ & $-92.60 \pm 4.42$ & $-90.36 \pm 4.31$ & $\mathrm{p}=0.072$ & $\mathrm{p}>0.05$ \\
\hline Epicardial adipose area $\left(\mathrm{cm}^{2}\right)$ & $20.92 \pm 12.57$ & $17.27 \pm 9.79$ & $\begin{array}{l}\mathrm{t}=1.24 \\
\mathrm{p}=0.215\end{array}$ & $\mathrm{p}>0.05$ \\
\hline $\begin{array}{l}\text { Subcutaneous adipose area } \\
\text { density (HU) }\end{array}$ & $-95.86 \pm 8.00$ & $-107.79 \pm 6.56$ & $\begin{array}{l}\mathrm{t}=6.15 \\
\mathrm{p}=0.001\end{array}$ & $\mathbf{p}<0.05$ \\
\hline $\begin{array}{l}\text { Subcutaneous adipose area } \\
\left(\mathrm{cm}^{2}\right)\end{array}$ & $111.53 \pm 78.96$ & $277.22 \pm 118.82$ & $\mathrm{p}=0.001$ & $\mathrm{p}<0.05$ \\
\hline Thorax area $(\mathrm{cm})$ & $95.93 \pm 9.36$ & $103.04 \pm 9.64$ & $\begin{array}{l}\mathrm{t}=2.61 \\
\mathrm{p}=0.011\end{array}$ & $\mathbf{p}<0.05$ \\
\hline RA: Rheumatoid arthritis, HU: $\mathrm{H}$ & $\begin{array}{r}\text { unsfield Unit, } \\
\text { devia }\end{array}$ & a: Millimeter, c & Centimeter, SD & tandard \\
\hline
\end{tabular}

It was seen that there was a significant difference in the EAT areas of patients with normal and increased CTR in the RA group $(\mathrm{p}<0.05)$.
Accordingly, the EAT area measurements of the RA patients with increased CTR were high (Table $3)$.

Table 3: Distribution of the epicardial adipose tissue area measurements of the patients in the RA group according to the cardiac thorax index

\begin{tabular}{|l|c|}
\hline CTR & EAT area (Mean \pm SD) \\
\hline Increased & $20.80 \pm 11.88 \mathrm{~cm}^{2}$ \\
\hline Normal & $14.92 \pm 8.52 \mathrm{~cm}^{2}$ \\
\hline Result & $\mathrm{t}=2.75 \mathrm{p}=0.007(\mathrm{p}<0.05)$ \\
\hline CTR: Cardiothoracic Ratio, EAT: Epicardial Adipose Tissue, SD: Standard deviation \\
\hline
\end{tabular}


According to the EAT area, the size of the area was found as 0.661 when a cut-off point is searched in the RA group, and the size of this area is statistically significant $(\mathrm{p}=0.002)$. Accordingly, the cut-off value for the EAT area in RA patients was found as $16.50 \mathrm{~cm}^{2}$, and the sensitivity for this as $52 \%$.

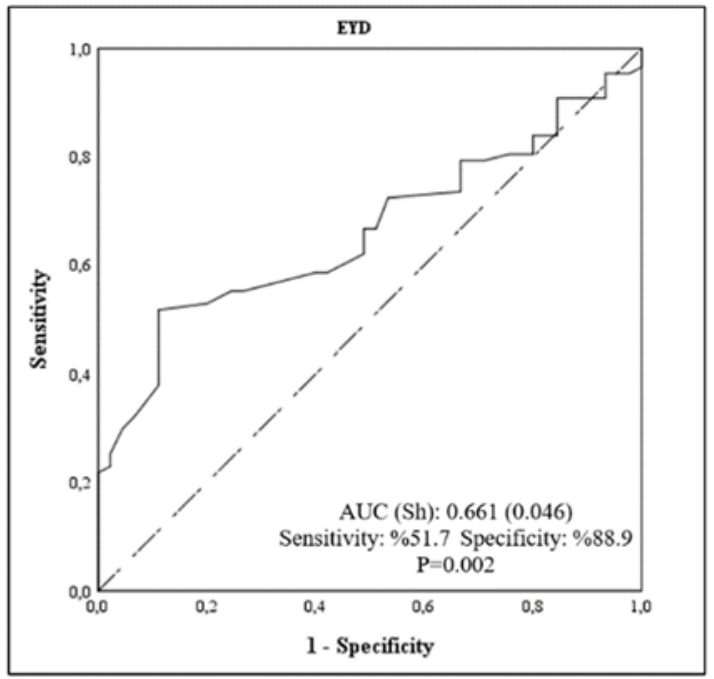

The cut-off value was found as $16.50 \mathrm{~cm}^{2}$ for the EAT area in patients diagnosed with RA (AUC:0.661, $\mathrm{p}<0.05$ ). When the patients were investigated according to the EAT cut-off value, it was determined that 42 patients were under, and 45 patients were above the cut-off value. A statistically significant difference was discovered when the ascending aorta diameters of the patients diagnosed with RA who were divided according to the EAT cut-off value $(\mathbf{p}<\mathbf{0 . 0 5})$ (Table 4).

Table 4: The relationship of EAT area with the increase in the ascending aorta diameter in patients diagnosed with RA

\begin{tabular}{|l|c|}
\hline \multicolumn{1}{|c|}{ EAT area $\left(\mathbf{c m}^{\mathbf{2}}\right)$} & Ascending aorta diameter $(\mathbf{m m})$ (Mean \pm SD) \\
\hline$\leq 16,50$ & $33,09 \pm 5,03$ \\
\hline$>16,50$ & $36,64 \pm 5,49$ \\
\hline Result: & $\mathbf{t}=3,13 ; \mathbf{p}=0,002$ \\
\hline EAT: Epicardial Adipose Tissue, SD: Standard Deviation \\
\hline
\end{tabular}

\section{DISCUSSION}

Although signs of polyarthritis and inflammation are the most prominent findings in patients with RA, non-negligibly increased CVDs are still the most common cause of death. About $39.6 \%$ of patients with RA die because of cardiovascular diseases $^{23}$. In large-scale studies, it was shown that there were increases at the rates of $48 \%$ and $50 \%$, respectively, in the major cardiovascular diseases and the cardiovascular disease associated death risk 7,24

Okada et al. ${ }^{25}$ measured the EAT volume and abdominal visceral adipose tissue area in nonobese patients and found that the EAT volume and CVD were highly correlated. They determined this as a risk factor independently of the body fat accumulation. In the present study, the fact that we found the EAT area high in the RA group is in accordance with the literature for it shows that the RA patients are at risk in terms of CVDs. Giles et al. ${ }^{26}$ determined that the increased visceral adipose tissue had a stronger correlation with CVDs compared to some cardiometabolic risk factors when the RA and control groups were compared. In the present study, it was determined that the EAT measured with CT increased compared to patients diagnosed with TA, and this increase was 
closely associated with the aortic and pulmonary artery width.

However, Oikawa et al. ${ }^{27}$ found that the EAT was a more sensitive indicator compared to the abdominal visceral adipose tissue in predicting coronary atherosclerosis. They measured the EAT with $\mathrm{CT}$ at the left significant coronary artery level and determined that it was $8.4(5.1-13.1) \mathrm{cm}^{2}$ in healthy individuals and 11.3 (7.4-16.5) in patients with calcification in the coronary artery. The fact that EAT area was determined to be high in patients with coronary artery plaques shows that EAT was strongly correlated with coronary diseases. Although no plaque was found in any of the individuals included in the present study, the fact that the EAT area of the RA patients was determined as $17.90 \pm 10.33$ might show that these patients were at high risk in terms of coronary artery disease.

Visceral adipose tissue is an active endocrine and paracrine organ which secretes many proinflammatory and pro-atherogenic cytokines. However, EAT is a unique form of visceral adipose tissue settled under the visceral pericardium. EAT is embryologically similar to intrabdominal visceral adipose tissue. EAT may affect coronary arteries by secreting various bioactive molecules 28,29. Many biochemical properties of EAT show that EAT was closely associated with the development of CVDs. In the present study, however, the subcutaneous adipose areas were measured as $248.65 \pm 128.97 \mathrm{~cm}^{2}$ in the RA group and as $225.68 \pm 128.87 \mathrm{~cm}^{2}$ in the control group, and there was no significant difference between the groups ( $>0.05)$. When the measurements of the males and females in the RA group were compared, the subcutaneous adipose area and thorax area were found statistically significantly higher in females $(p<0.05)$. It is considered that this difference was because of the fact that the breast adipose tissue entered the cross-sectional area in female patients in the thorax CT section where the adipose analysis was made.

It was shown that the EAT was a stronger and more important risk factor compared to the fatty tissues in other regions of the body in terms of CVD development ${ }^{30}$. The results of the studies performed related to the EAT thickness in previous periods were based on the ECHO findings and the measurements could mostly and only be done on the EAT adjacent to the right ventricle or the pericardial and epicardial adipose tissue ${ }^{30-33}$. In these studies, it was emphasized that it was hard to make a distinction between the epi- and pericardial adipose tissues ${ }^{34}$. While the EAT could be evaluated through the ECHO and CT, cardiac MR is accepted as the gold standard method in our day 11,35. Cardiac MR is a hard and time-consuming method which requires experienced staff for the evaluation. Therefore, it is often used in clinical studies in our day.

However, cardiac CT is an imaging method which provides more objective findings compared to ECHO for the evaluation of the EAT, and it gives results independently of any individual thanks to appropriate software ${ }^{17-20}$. In the present study, the EAT measurement was evaluated through the thorax CT with proper software. The measures to be carried out by a radiologist in a way to provide practical and objective results were considered as a remarkable and positive situation in our study.

Wallberg-Jonsson et al. ${ }^{36}$ reported that the death risk because of cardiovascular reasons in patients with RA increased at the rates of 1.64 in females and 1.47 in males and these rates were significantly higher compared to a healthy population. RA is more frequently seen in females compared to males (2:1) and it peaks in the fifties ${ }^{2,3,37}$. In the present study, it was determined that most of the patients diagnosed with RA were females with a mean age of $54.58 \pm 11.49$ in accordance with the literature (82.8\% vs. $17.2 \%)$.

Ormseth et al. ${ }^{12}$ measured the EAT volume as $108.2 \mathrm{~cm}^{3}(77.0-144.6)$ in the RA and as $93.9 \mathrm{~cm}^{3}$ (69.9-133.1) in the control group and showed that there was no statistically significant difference between the two groups. Oyama et al. ${ }^{38}$ measured the EAT area at the levels of the right coronary artery, right pulmonary artery, coronary sinus and left major coronary artery and reported that the EAT area at the left major coronary artery level could show the total EAT volume at the best level. In that study, the EAT area at the left major coronary artery level was $4.4 \pm 2.0 \mathrm{~cm}^{2}(0.7-11.5)$, while in the present study, the EAT area in the RA group was significantly higher than the control group (17.90 $10.33 \mathrm{~cm}^{2}$ vs. $\left.11.92 \pm 5.24 \mathrm{~cm}^{2}\right)$ $(\mathrm{p}<0.05)$. The EAT areas determined in the present study was higher than the studies mentioned. It is considered that the fact that the patients with $\mathrm{BMI} \geq 30 \mathrm{~kg} / \mathrm{m}^{2}$ were excluded from the study by Oyama et al. ${ }^{38}$ caused lower results compared to those of the present study.

Kırış et al. ${ }^{39}$ measured the EAT thickness in the patient group without the bundle branch block in the heart and determined a strong correlation between the increased EAT thickness and left ventricle dysfunction (LVD) and hypertrophy (LVH). Similarly, Watanabe et al. ${ }^{40}$ determined that the increase in the EAT thickness was closely 
associated with the protected EF LVD. In the present study, it was seen that the CTR increase in RA patients was closely associated with the increased EAT area $(\mathrm{p}<0.05)$.

In many recent studies related to the measurements of the aortic arch (AA), it was shown that the AA diameter is an indicator of deaths due to congestive heart failure, stroke, and CVDs. Changes in the extracellular matrix play a key role in the aortic dilatation pathogenesis. EAT may cause dilatation in the ascending aorta with the systemic endocrine effects or local paracrine and passive thermogenic effects on the vascularization. In many of the recent studies conducted on the aortic root measurements, the AA diameter was shown as an important indicator of congestive heart failure, stroke and CVD related deaths ${ }^{41-43}$. Çanga et al. ${ }^{44}$ showed that the increase in the EAT thickness was associated with the increase in the ascending aorta diameter. In the present study, when the cut-off value for the EAT area was determined as 16.50 $\mathrm{cm}^{2}$, the AA diameter was measured as $33.09 \pm 5.03$ $\mathrm{mm}$ in the group remaining under and as $36.64 \pm 5.49 \mathrm{~mm}$ in the group remaining above the cut-off value $(\mathrm{p}<0.05)$.

The present study has some limitations. The retrospective nature of the study caused the absence of the chance of simultaneously evaluating the other CVD risk indicators such as carotid intima-media thickness (CIMT), ECHO, and EKG. In addition, the patients could not be assessed in terms of significant cardiovascular outcomes (such as MI, stroke, and death). In addition, the fact that the study was conducted only in Turkish society causes that its results cannot be generalized for other nations. However, the fact that the RA diagnosed patients in this study did not use medical treatment was considered as an essential advantage for the evaluation of EAT in the early period of RA.

As a result, in the present study, it was determined that the EAT evaluated with CT increased in RA patients compared to healthy individuals, and this increase was associated with the aortic and pulmonary artery width. In addition, it was seen that the rise in the EAT area in RA patients was directly proportional to the CTR. The RA patients were significantly at risk for the development of CVDs. It is considered that prospective studies including more patients diagnosed with RA are needed on this subject.

\section{REFERENCES}

1. Hunter TM, Boytsov NN, Zhang X, Schroeder $\mathrm{K}$, Michaud K, Araujo AB. Prevalence of rheumatoid arthritis in the United States adult population in healthcare claims databases, 2004-2014. Rheumatol Int. 2017 Sep;37(9):1551-7.

2. Tuncer T, Gilgil E, Kaçar C, Kurtaş Y, Kutlay Ş, Bütün B, et al. Prevalence of Rheumatoid Arthritis and Spondyloarthritis in Turkey: A Nationwide Study. 2018;33(2):128-36.

3. van Vollenhoven RF. Sex differences in rheumatoid arthritis: more than meets the eye... BMC Med. 2009;7:12.

4. Crowson CS, Liao KP, Davis JM 3rd, Solomon $\mathrm{DH}$, Matteson EL, Knutson KL, et al. Rheumatoid arthritis and cardiovascular disease. Am Heart J. 2013 Oct;166(4):622628.e1.

5. Mellana WM, Aronow WS, Palaniswamy C, Khera S. Rheumatoid arthritis: cardiovascular manifestations, pathogenesis, and therapy. Curr Pharm Des. 2012;18(11):1450-6.

6. Kaplan MJ. Cardiovascular complications of rheumatoid arthritis: assessment, prevention, and treatment. Rheum Dis Clin North Am. 2010 May;36(2):405-26.

7. Avina-Zubieta JA, Thomas J, Sadatsafavi M, Lehman AJ, Lacaille D. Risk of incident cardiovascular events in patients with rheumatoid arthritis: a meta-analysis of observational studies. Ann Rheum Dis. 2012 Sep;71(9):1524-9.

8. Corrao S, Messina S, Pistone G, Calvo L, Scaglione R, Licata G. Heart involvement in Rheumatoid Arthritis : Systematic review. Int J Cardiol. 2012;

9. England BR, Thiele GM, Anderson DR, Mikuls TR. Increased cardiovascular risk in rheumatoid arthritis : mechanisms and implications. :1-17.

10. Wu Y, Zhang A, Hamilton DJ, Deng $T$. Epicardial Fat in the Maintenance of Cardiovascular Health. Methodist Debakey Cardiovasc J. 2017;13(1):20-4.

11. Bertaso AG, Bertol D, Duncan BB, Foppa M. Epicardial fat: definition, measurements and systematic review of main outcomes. Arq Bras Cardiol. 2013 Jul;101(1):e18-28.

12. Ormseth MJ, Lipson A, Alexopoulos N, Hartlage GR, Oeser AM, Bian A, et al. Association of epicardial adipose tissue with cardiometabolic risk and metabolic syndrome in patients with rheumatoid arthritis. Arthritis Care Res (Hoboken). 2013 Sep;65(9):1410-5.

13. Lima-Martínez M, Campo E, Salazar J, Paoli 
M, Maldonado I, Acosta C, et al. Epicardial Fat Thickness as Cardiovascular Risk Factor and Therapeutic Target in Patients with Rheumatoid Arthritis Treated with Biological and Nonbiological Therapies. Arthritis. 2014;2014:782850.

14. Fatma E, Bunyamin K, Savas S, Mehmet U, Selma Y, Ismail B, et al. Epicardial fat thickness in patients with rheumatoid arthritis. Afr Health Sci. 2015 Jun;15(2):489-95.

15. Nafakhi H, Al-Mosawi A, Al-Nafakh H, Tawfeeq N. Association of pericardial fat volume with coronary atherosclerotic disease assessed by CT angiography. Br J Radiol. 2014 Jun 21;87(1038):20130713.

16. Hwang I-C, Park HE, Choi S-Y. Epicardial Adipose Tissue Contributes to the Development of Non-Calcified Coronary Plaque: A 5-Year Computed Tomography Follow-up Study. J Atheroscler Thromb. 2017 Mar;24(3):262-74.

17. Mancio J, Azevedo D, Saraiva F, Azevedo AI, Pires-Morais G, Leite-Moreira A, et al. Epicardial adipose tissue volume assessed by computed tomography and coronary artery disease: a systematic review and meta-analysis. Eur Heart J Cardiovasc Imaging. 2018 May;19(5):490-7.

18. Demircelik MB, Yilmaz OC, Gurel OM, Selcoki Y, Atar IA, Bozkurt A, et al. Epicardial adipose tissue and pericoronary fat thickness measured with 64-multidetector computed tomography: potential predictors of the severity of coronary artery disease. Clinics (Sao Paulo). 2014 Jun;69(6):388-92.

19. Nagy E, Jermendy AL, Merkely B, MaurovichHorvat P. Clinical importance of epicardial adipose tissue. Arch Med Sci. 2017 Jun;13(4):864-74.

20. Mahabadi AA, Balcer B, Dykun I, Forsting M, Schlosser T, Heusch G, et al. Cardiac computed tomography-derived epicardial fat volume and attenuation independently distinguish patients with and without myocardial infarction. 2017;1-11.

21. Arnett FC, Edworthy SM, Bloch DA, McShane DJ, Fries JF, Cooper NS, et al. The American Rheumatism Association 1987 revised criteria for the classification of rheumatoid arthritis. Arthritis Rheum. 1988 Mar;31(3):315-24.

22. Aletaha D, Neogi T, Silman AJ, Funovits J, Felson DT, Bingham CO 3rd, et al. 2010 Rheumatoid arthritis classification criteria: an
American College of Rheumatology/European League Against Rheumatism collaborative initiative. Arthritis Rheum. 2010 Sep;62(9):2569-81.

23. Sokka T, Abelson B, Pincus T. Mortality in rheumatoid arthritis: 2008 update. Clin Exp Rheumatol. 2008;26(5 Suppl 51):S35-61.

24. Avina-Zubieta JA, Choi HK, Sadatsafavi M, Etminan M, Esdaile JM, Lacaille D. Risk of cardiovascular mortality in patients with rheumatoid arthritis: a meta-analysis of observational studies. Arthritis Rheum. 2008 Dec;59(12):1690-7.

25. Okada $\mathrm{K}$, Ohshima $\mathrm{S}$, Isobe $\mathrm{S}$, Harada $\mathrm{K}$, Hirashiki A, Funahashi H, et al. Epicardial fat volume correlates with severity of coronary artery disease in nonobese patients. $\mathrm{J}$ Cardiovasc Med (Hagerstown). 2014 May;15(5):384-90.

26. Giles JT, Allison M, Blumenthal RS, Post W, Gelber AC, Petri M, et al. Abdominal adiposity in rheumatoid arthritis: association with cardiometabolic risk factors and disease characteristics. Arthritis Rheum. 2010 Nov;62(11):3173-82.

27. Oikawa M, Owada T, Yamauchi H, Misaka T, Machii H, Yamaki T, et al. Epicardial adipose tissue reflects the presence of coronary artery disease: comparison with abdominal visceral adipose tissue. Biomed Res Int. 2015;2015:483982.

28. Amigues I, Tugcu A, Russo C, Giles JT, Morgenstein R, Zartoshti A, et al. Myocardial Inflammation, Measured Using 18Fluorodeoxyglucose Positron Emission Tomography-Computed Tomography (FDG PET-CT) is Associated with Disease Activity in Rheumatoid Arthritis. Arthritis Rheumatol. 2018;

29. Kalinkovich A, Gabdulina G, Livshits G. Autoimmunity, inflammation, and dysbiosis mutually govern the transition from the preclinical to the clinical stage of rheumatoid arthritis. Immunol Res. 2018 Nov;

30. Taguchi R, Takasu J, Itani Y, Yamamoto R, Yokoyama K, Watanabe S, et al. Pericardial fat accumulation in men as a risk factor for coronary artery disease. Atherosclerosis. 2001 Jul;157(1):203-9.

31. Iacobellis G, Ribaudo MC, Zappaterreno A, Iannucci CV, Leonetti F. Relation between epicardial adipose tissue and left ventricular 
mass. Am J Cardiol. 2004 Oct;94(8):1084-7.

32. Iacobellis G, Assael F, Ribaudo MC, Zappaterreno A, Alessi G, Di Mario U, et al. Epicardial fat from echocardiography: a new method for visceral adipose tissue prediction. Obes Res. 2003 Feb;11(2):304-10.

33. Iacobellis G, Ribaudo MC, Assael F, Vecci E, Tiberti C, Zappaterreno A, et al. Echocardiographic epicardial adipose tissue is related to anthropometric and clinical parameters of metabolic syndrome: a new indicator of cardiovascular risk. J Clin Endocrinol Metab. 2003 Nov;88(11):5163-8.

34. Abbara S, Desai JC, Cury RC, Butler J, Nieman $\mathrm{K}$, Reddy V. Mapping epicardial fat with multidetector computed tomography to facilitate percutaneous transepicardial arrhythmia ablation. Eur J Radiol. 2006 Mar;57(3):417-22.

35. Kessels K, Cramer M-JM, Velthuis B. Epicardial adipose tissue imaged by magnetic resonance imaging: an important risk marker of cardiovascular disease. Heart. 2006 Jul;92(7):962.

36. Wallberg-Jonsson S, Ohman ML, Dahlqvist SR. Cardiovascular morbidity and mortality in patients with seropositive rheumatoid arthritis in Northern Sweden. J Rheumatol. 1997 Mar;24(3):445-51.

37. O'Neill TW, McCabe PS, McBeth J. Update on the epidemiology, risk factors and disease outcomes of osteoarthritis. Best Pract Res Clin Rheumatol [Internet]. 2018;(xxxx). Available from:

https://doi.org/10.1016/j.berh.2018.10.005

38. Oyama N, Goto D, Ito YM, Ishimori N, Mimura R, Furumoto T, et al. Single-slice epicardial fat area measurement: do we need to measure the total epicardial fat volume? Jpn J Radiol. 2011 Feb;29(2):104-9.
39. Kiris A, Kiris G, Turan OE, Ozturk M, Sahin $\mathrm{M}$, Ilter $\mathrm{A}$, et al. Relationship between epicardial fat tissue and left ventricular synchronicity: An observational study. Anatol J Cardiol. 2015;15(12):990-4.

40. Watanabe K, Kishino T, Sano J, Ariga T, Okuyama S, Mori $\mathrm{H}$, et al. Relationship between epicardial adipose tissue thickness and early impairment of left ventricular systolic function in patients with preserved ejection fraction. Heart Vessels. 2016 Jun;31(6):1010-5.

41. Cui X, Li Y, Liu J, He S, Liu M. Aortic arch atheroma and the risk of stroke: a meta-analysis. J Evid Based Med. 2014 Aug;7(3):185-91.

42. Lee R, Kim J, Paeng JC, Byun JW, Cheon GJ, Lee DS, et al. Measurement of (68)GaDOTATOC Uptake in the Thoracic Aorta and Its Correlation with Cardiovascular Risk. Nucl Med Mol Imaging (2010). 2018 Aug;52(4):279-86.

43. Nguyen-Thu H, Ohyama Y, TaketomiTakahashi A, Nguyen-Cong T, Sugimoto A, Sato M, et al. Association of Aortic Arch Width Assessed by Noncontrast Cardiac Computed Tomography with Cardiac Remodeling, Cardiac Function, and Atherosclerosis in a Japanese Cohort. J Thorac Imaging. 2018;33(4):240-5.

44. Canga A, Kocaman SA, Cetin M, Erdogan T, Durakoglugil ME, Cicek Y, et al. Increased epicardial adipose tissue thickness is correlated with ascending aortic diameter. Tohoku J Exp Med. 2012 Mar;226(3):183-90. 